\title{
The Chernobyl disaster: A case study on the information policy of the Kádár regime
}

\author{
Dalma Kékesdi-Boldog \\ ORCID: 0000-0002-0282-4818
}

CORVINUS UNIVERSITY OF BUDAPEST, HUNGARY

DOI: 10.19195/1899-5101.12.1(22).5

\begin{abstract}
While the Hungarian Socialist Workers' Party was on the rhetorical level committed to the Soviet agitation and propaganda model, in practice it increasingly deviated from it during the 1980s. As the press reflected upon the events of the day, propaganda could manifestly be at odds with reality, creating a reality gap, that is, one between what people were told to see and what they actually saw. This paper offers a case study on the communication of the Chernobyl nuclear disaster in Hungary and looks into how it was reflected in party communiqués, the party newspaper, and opinion polls. It asks the question of whether 'accuracy' or 'partisanship' prevailed in the official communication of the disaster.
\end{abstract}

KEYWORDS: Chernobyl disaster, Hungary, information policy, partisanship, public opinion, Népszabadság.

\section{INTRODUCTION}

There was a slow democratisation and cultural opening process going on in the 1980s in Hungary (Valuch, 2005, pp. 67-68; Romsics, 1999, pp. 450-456). Even though the Hungarian Socialist Workers' Party (MSZMP) was on the rhetorical level committed to the Soviet model, the actual practice of information policy was not in line with it all of the time. János Kádár, the general secretary of the party wanted to break with the former Rákosi regime's information policy and had a de-Stalinisation attitude with a détente effect (Földes, 2012, pp. 200-214; Takács, 2013, pp. 84-90). Furthermore, the Hungarian leadership had to meet both Soviet and Western expectations, given the ongoing economic crisis and the heavy foreign debts of the country (Csizmadia, 
2012, p. 194). In addition, the press could not always act as an agitator and propagandist (Bajomi-Lázár, 2005, p. 24), because in practice it strived to reflect upon the everyday events that were not in line with the state-socialist ideology. Media were considered the transmission belts of the party state, and mass communication was used as a propaganda instrument (Siebert et al., 1956, pp. 105-146). Propaganda could not manifestly be at odds with reality and hence may have created a reality gap, that is, one between what people were told to see and what they actually saw (Jakubowicz, 2011, p. 388). It is my assumption that this fear from the reality gap was driving Hungarian information policy makers to adapt to ideologically sensitive cases that did not fit into the authoritarian media system. This paper offers a case study on the communication of the 1986 Chernobyl nuclear disaster in Hungary and looks into how it was reflected in party communiqués, the party newspaper Népszabadság (The people’s freedom) and opinion polls. It asks the question of whether 'accuracy' or 'partisanship' prevailed in the official communication of the disaster. ${ }^{1}$

\section{THE ACCIDENT AND ITS POLITICAL CONTEXT}

The fatal accident that occurred in the Vladimir Ilyich Lenin Nuclear Power Station on 26 April 1986 involved two explosions in Reactor No. 4 that damaged the 3,000 ton roof of the power plant, which was thrown up 50 metres into the air and fell back onto the middle part of the reactor. A 750-metre-high fire broke out and kept burning for 10 days (Aszódi, 2006). The effused radioactive fall-out polluted an area of over 30,000 square kilometres.

The accident was caused by contributory negligence. The operators of the power plant wanted to test a special speed control tool, but did not observe the protocol during the experiment. The catastrophe could have been avoided, had at least one of these rules been observed (INSAG-7, 1992, pp. 51-89).

Three types of indirect antecedents caused the accident (Szatmáry \& Aszódi, 2010, pp. 90-98). Firstly, construction mistakes: the RBMK-type power stations, like the one in Chernobyl, were already an outdated technology and had a complicated control mechanism. Secondly, there were management problems: it was definitely prohibited to make any kind of experiment in an active nuclear plant. The staff was not aware of the danger; the work plan broke several rules and was not approved by the managers responsible for the safety of the power plant (INSAG-7, 1992, pp. 51-89). Thirdly, there was an institutionalised ideological and geopolitical conflict between the United Sates and the Soviet Union during the Cold War. The permanent chase for spectacular scientific results often came at the expense of technological elaboration,

1 The party's Political Committee declared in 1979 that " $t$ t he press should be collaborative and give voice to the proletariat without question, its viewpoint must be the same as the class position. [...] Partyspiritedness and commitment are required from journalists" (the official source cited by Hegedüs, 2001). By contrast, the first press law, passed in 1986, stated that "[t]he job of the press is to provide authentic, precise and up-to-date information" (1986. évi II. törvény a sajtóról 2\$ (1) [Press law 1986/II]). 
and also manifested itself in the building of nuclear reactors. The Chernobyl disaster had medical, social, economic as well as political consequences; it was a sensitive case in point in the history of the bipolar world system which significantly influenced the status of the Soviet superpower. It was an 'anthropological shock' which changed everyday life (Beck, 1987, p. 156), because it had familial, medical and environmental aftereffects (Harper, 2001) and the continuous attention to the healthcare recommendations reminded people of the danger.

In Hungary, a Soviet-based but more flexible information policy was gradually emerging during the Kádár regime’s last decade. Glasnost (openness) and perestroika (restructuring), managed by Mikhail Gorbachev from 1986 also had an impact on Hungary's information policy. The first Hungarian press law, passed in 1986, did not define the party's role in media policy making (Takács, 2009, 2012), it declared the ideal of 'accuracy', but - unlike the previous official statements - did not mention 'partisanship'. The infamous differentiated information policy, managed by Minister of Culture György Aczél, listed authors and their works into 'tolerated, 'prohibited' and 'supported' categories. But this semi-formal and unwritten policy did not offer clear classification criteria (Sipos, 2015, pp. 36-38). In practice, mass communication was informally managed via methods such as the destroying of some printed newspapers, the jamming of foreign radio frequencies and the so-called press plans prescribing how certain political events must be covered (Bajomi-Lázár, 2005, pp. 25-28). Even though there was no official censorship, the press was controlled by an extensive institutional system and bureaucracy, the founding of newspapers and the training of journalists (Takács, 2012). The state-socialist ideology was chiefly maintained by the state security organisations and by the centralisation of resources. The main device of indirect control was state monopoly in a variety of fields, including intelligence (the hegemony of the Hungarian News Agency), the paper industry (printing houses owned by the party state), publishing houses (managers and editors nominated based on a nomenklatura system), as well as a system of privileges offered to collaborating journalists (Bajomi-Lázár, 2005; Sipos 2010, 2015).

\section{RESEARCH DESIGN}

This research is a source-based descriptive analysis containing three elements. Firstly, it offers an overview of the archival sources available in the Hungarian National Archive on the Hungarian Socialist Workers' Party's organisational communication in order to describe the process whereby the party attempted to temporally structure information about Chernobyl. As the next step, it reconstructs the narratives of the official party newspaper Népszabadság in an attempt to reveal the nature of the information designed for the public. Finally, it describes and interprets the findings of the opinion polls conducted by the Mass Communication Research Center in 1986 on the perception of the accident. 
This paper is expected to disclose how Hungarian information policy worked in practice. It is anticipated that the unprecedented, unexpected and extreme situation created by the disaster will show like a magnifying glass the usual practices of the information policy of the party state. The main research question was that of which facts the press reported on and what kind of information the party marginalised. A chronological table summarising the content of the primary sources shows what the party knew about the accident, and what information was released via the press (see Table 1). Measurement data on the level of nuclear radiation, gathered by the Hungarian Technical Council, are also listed in this table.

\section{The communiqués of the Hungarian Socialist Workers' Party}

Because of the extensive bureaucracy of the Hungarian state-socialist regime, dozens of official communiqués were issued about the Chernobyl nuclear accident. I selected 11 official releases made public between 29 April and 16 May. This was the most important period in that the news blackout was unlocked, the information was slowly becoming richer, new facts and circumstances of the accident were revealed every day, and experts and responsible officials made a number of statements. Diverse types of documents (reports by the minister of industry and by the commander of National Civil Defence, the records of the Political Committee's Economic Section, a note by the Secretariat of the National Atomic Energy Commission, other protocols and verbatim reports) representing various levels of the party hierarchy were selected in an attempt to show variations and contradictions within the party discourse. This analysis does not cover official documents discussing the geopolitical, economic and touristic effects of the accident, as this section of my research aimed chiefly at revealing when and under what circumstances the party itself was informed about the details of the accident.

\section{The articles of Népszabadság}

This narrative analysis was based on the articles of the official Hungarian communist newspaper Népszabadság. I studied the editions issued between 29 April and 19 May 1986. This period was chosen as this is when most of the relevant articles were published. The selection was based on the following keywords: (background) radiation, radioactive, emission, fall-out. Only the Hungary-related news items were selected; hence my analysis does not cover information on neighbouring countries, nor reflections of 'Western' news reports.

The sample thus compiled contains 18 items. I examined the article's position within the newspapers (front page or internal page), and counted the number of words the articles in question used when describing the accident and its aftermath. Finally, I categorised the items in line with what they stated about the radiation. The wording and the context were also analysed. 


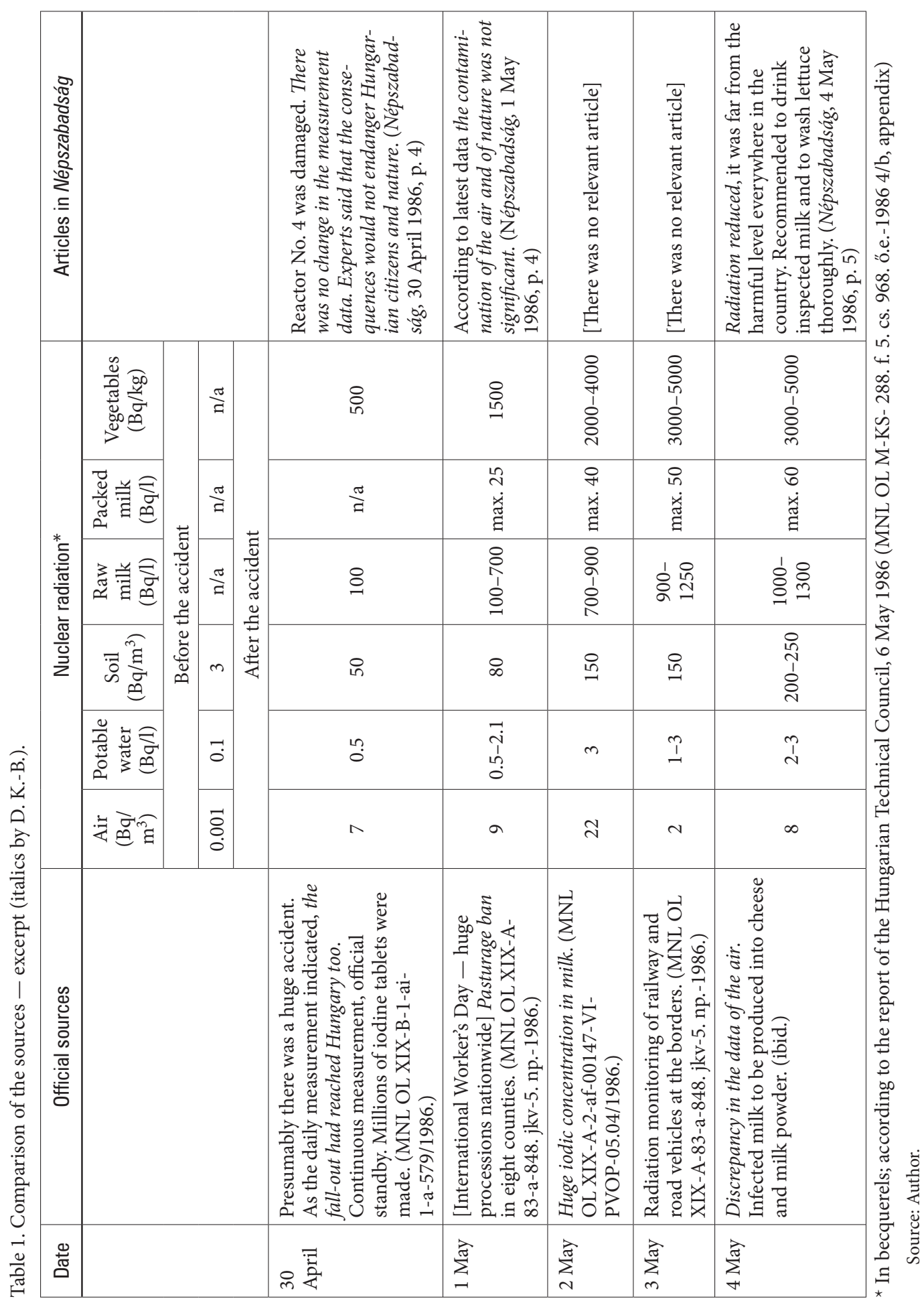


Because of the information monopoly of the state, all journalists were to rely on the press releases of the Hungarian News Agency. This suggests that it is sufficient to study one newspaper only, as the articles in Népszabadság are largely representative of the whole media at that time.

\section{Opinion polls}

I did a secondary analysis of two opinion polls conducted by the Mass Communication Research Centre about the perception of the Chernobyl disaster in 1986. The data were generated for internal party use. My analysis focused on people's opinions about the Hungarian news reports.

Although the Mass Communication Research Centre was not fully independent from the party's ideological expectations and state security supervision, it was relatively autonomous (Terestyéni, 2009; Vásárhelyi, 2016). Despite the centre’s semidependent position, the polls it conducted are widely considered reliable sources.

\section{FINDINGS}

\section{The communication of the party}

The first official 'top secret' communiqué was issued on 29 April, three days after the accident. It was a report by Minister of the Industry László Kapolyi stating that the Soviets asked Hungary to reduce the volume of its electricity imports because there had occurred an 'error' in the Chernobyl power plant. Hungarian authorities did not receive more information about this. Non-official Western sources, however, had notified Hungary on 26 April that the base level of background radiation had displayed a six-fold increase (MNL OL XIX-A-2af-Ma-00147-VII-szn/1986; MNL OL XIX-A-41-II). On 30 April, Commander of the National Civil Defence Mihály Berki reported that "presumably, a major nuclear accident happened in Chernobyl, Reactor No. 4 had broken down during the night of 25 April" (MNL OL XIX-B-1-ai-1-a$579 / 1986){ }^{2}$ As daily measurements indicated, the nuclear fall-out had reached Hungary. According to the commander, the radiation counts per minute (cps) level was 10 to 20 times higher than before. He observed that "the Soviet comrades have not given us information". A Hungarian expert team was established to conduct measurements on a permanent basis. The Ministry of Industry called for a million iodine tablets to be produced (MNL OL XIX-A-83-a-848. jkv-5. np.-1986. 5/c).

The next official document was issued by the Economic Section of the Political Committee on 6 May, and read that Hungarian leaders had received official information about the nuclear accident on 28 April from the Soviets (MNL OL M-KS- 288. f. 5. cs. 968. ö.e.-1986. 4/b). It also mentioned non-official Swedish, Polish and Finnish notifications released on 26 April and added that the nuclear cloud had reached Hungary during the night of 29 April and, spreading westward,

\footnotetext{
2 All cited fragments in the Author's own translation.
} 
had infected almost all of the country's territory. According to the report of the Hungarian Technical Council, the level of radioactive air pollution was many times above normal, and the contamination of surface water and potable water was almost two times higher than before. Food and soil measurement data indicated that the level of harmful radiation was not remarkable (MNL OL M-KS- 288. f. 5. cs. 968. ö.e.-1986 4/b, appendix). It was necessary to dilute infected milk with clean milk to sell a special mixture milk, because the level of radiation had risen hundreds of times beyond normal in raw milk. The Ministry of Agriculture and Food recommended that lettuce should be thoroughly washed because of the surface pollution, and that people should buy packed milk. A pasturage ban was imposed in six counties on 1 May, and was three days later ordered in sixteen counties (MNL OL XIX-B-1-y-1986.05.12. 7/b). Other reports noted that the feeding of animals caused difficulties to farmers (e.g., MNL OL M-KS- 288. f. 5. cs. 968. ö.e.-1986. 4/c; MNL OL XIX-A-83-a-848. jkv-5. np.-1986. 5/c; MNL OL XIX-B-1-y-1986.05.12. $7 / \mathrm{b})$. The above-mentioned report of the Technical Council was also discussed by the Political Committee on 6 May, the notes taken during the meeting show the uncertainty generated among the country's leaders:

we should not act by emotion [...] it is necessary to impose censorship on the expert team [...] there is a great deal of pressure on us [...] we must remove politically misleading articles from the papers $[\ldots]$ or else we will be in political trouble [...] we have to inform the people $[\ldots]$ we will only publish the Soviet news, not western 'omnifarious' information (MNL OL M-KS- 288. f. 5. cs. 968. ő.e.-1986. 4/c).

Concluding the report and summarising the expected impacts of the accident, the Secretariat of the National Atomic Energy Commission published a long note for internal use (MNL OL XIX-A-41-II.) stating that "a large amount of nuclear radiation has reached Hungary" with "multiple effects". The Secretariat also considered the long-term outcomes of the presence of radioactive isotopes (added into the food chain; human diseases, etc.), as well as the political, economic and touristic aftereffects of the accident. The report highlighted that the Soviets had not given adequate information about the Chernobyl case, leaving Hungarian specialists in obscurity.

The official documents always mentioned the level of nuclear radiation, which changed on a daily basis during the studied period, and evinced geographical differences. The first document reporting a decrease was issued on 16 May and read that "radiation was not detectable, there is no danger" (MNL OL M-KS- 288. f. 22. cs. 86. ő.e.).

\section{Newspaper articles}

The first article about the Chernobyl nuclear disaster was published in Népszabadság on 29 April, that is, the party's official newspaper was three days late in reporting the event. The article was on an internal page and informed readers about the 
accident in only 105 words. It made very general statements such as "the injured were given medical attention" and "a special expert group was established". Nuclear radiation was not mentioned as yet. None of the 18 articles in the sample stated clearly that harmful nuclear radiation had reached Hungarian airspace.

The quotes below are about the presence of nuclear radiation:

According to current measurements, radiation in Hungary is far from the harmful level [...] the experts recommend drinking inspected milk and washing lettuce thoroughly (Népszabadság, 4 May 1986, p. 5).

The director of the Frédéric Joliot-Curie Radiation Biology Institute of Hungary said [...] that there was radioactive iodic isotope in the Hungarian atmosphere [...] the radioactive iodine polluted the grass, spread to the ground, and eventually every radioactive particle settles (Népszabadság, 5 May 1986, p. 3).

These articles were published on successive days a week after the accident. Even a superficial comparison discloses a great deal of dissonance between the two: while the first referred to official measurement data claiming that "there was no harmful radiation in Hungary". The second cited an expert saying that "radioactive iodic isotopes were found everywhere".

There was only one more article which hinted at the increase in the level of radiation. It read that "the increase of radioactivity in the atmosphere and environment is not significant". (Népszabadság, 1 May 1986). However, the headline on the previous day was this: "Radioactivity did not increase in Hungary's atmosphere" (Népszabadság, 30 April 1986, p. 4). Comparing the two articles, it is clear that stating that something did not significantly increase, does not mean that it did not increase at all.

In terms of the position of the articles published in Népszabadság, there were seven front-page reports about Chernobyl, of which only three had a Hungarian relevance. The rest of them mentioned Hungary only on the internal page. The first front-page article was published ten days after the accident, the second one five days later, and the third one came out on 16 May. The first article, covering one quarter of the front page, was a report from an international press conference where experts stated that measurements were permanently being made, but the Soviets did not know what exactly had happened. This text devoted 37 words to Hungary. In this article the vice-chairman of the Soviet Meteorological State Committee said that "[ $\mathrm{t}]$ he Chernobyl accident did not endanger the Hungarian population" (Népszabadság, 7 May, 1986). The article continued on page 3 with a 153 -word-long report about current radiation data. According to this, "nuclear radiation in Hungarian airspace was very low, and has been reducing in the two previous days".

The next front-page article, covering one quarter of the page, was published on 12 May with a Hungarian-related 74-word-long section. Its subheader suggested that "[r]adioactivity has further decreased in Hungarian airspace" (Népszabadság, 12 May, 1986). This was the only front-page article with a photo of the exploded 
power plant. There was also a long article on page 3, filling almost half of the page, with one-third of the text including information relevant for Hungary. At first sight, it was a precise, 440-words-long statement of two Hungarian experts. They used three different kinds of measurement units to express how low the level of radiation was in Hungary, but this was more confusing than calming.

The last front-page article was released on 16 May, covering one third of the page, summarising the circumstances and medical effects of the nuclear accident in 698 words, devoting 25 words to Hungarian measurement data and stating that "natural background radiation has decreased to the pre-accident value" (Népszabadság, 16 May, 1986).

Despite the repeated underlining of the reducing level of nuclear radiation, three articles completely denied the fact of radiation. One day after the accident was announced in Hungary, Népszabadság published the following sentences: "Air measurements data showed no differences after the Chernobyl accident in the Hungarian atmosphere. According to experts, the damage in the reactor would not endanger the Hungarian people and nature" (Népszabadság, 30 April 1986, p. 4). One day later, experts of the National Civil Defence said that according to the measurement data "the increase in nuclear radiation was not remarkable, the measured values are very similar to the usual ones" (Népszabadság, 1 May 1986, p. 4). A week later, there was an article on the front page about an international press conference held in Moscow. The first lines said that Hungary was not endangered by the Chernobyl accident in terms of radiant molecules (Népszabadság, 7 May 1986). The last article was published two days later with Soviet experts highlighting this on the front page: "There was no nuclear explosion in Chernobyl, the amount of the fall-out was overreacted by the western press" (Népszabadság, 9 May 1986, p. 1).

In terms of the wording, one article said that radiation in Hungary "has not increased, and another that it has not increased significantly". Three of them wrote about "fluctuation", five of them asserted that radiation had been "continuously decreasing". One article mentioned that "radiation was at a low level". Finally, four articles said that radiation had "actually decreased" to pre-accident values. In sum, most of the statements created a relational system with a former higher value and the current value that was lower than the previous one. This suggested, between the lines, that the radiation had increased in the previous period.

The recommendations of the National Civil Defence - people should drink inspected milk only and wash lettuce thoroughly because of the settled pollution - were continuously published, even when the World Health Organization already stated that raw milk was potable (Népszabadság, 8 May 1986, p. 3).

\section{Public opinion}

The Mass Communication Research Centre conducted two opinion polls about the disaster. The first survey was made on 5 and 6 May, one week after Chernobyl (HU OSA-420-2-2:1 A8203) on a sample of 413 people in Budapest. This sample 
was non-representative, but offered meaningful information in terms of some specific social groups (under and over 40 years of age, white and blue collar workers, pensioners). The survey disclosed that people were gathering information more intensely than before the accident: 79 percent of the interviewees said that they were paying more attention to the news; one third of them also listened to 'Western' radio stations too, such as Radio Free Europe, BBC World and the Voice of America. Some 67 percent of the respondents were partly or wholly dissatisfied with the news reports of the Hungarian media. Almost every second person had doubts about the reliability of official information. Those dissatisfied mentioned the following causes: the information was deficient, belated and relied on Soviet sources only, it was not accurate, and hushed up the facts and misled the people.

The second survey was conducted two weeks later, on 16 and 18 May (HU OSA420-2-2:1 A8204) on a sample of 414 people in Budapest. It was based on the same social groups, and disclosed changes in public opinion. Information gathering was intense: 67 percent of respondents said that they were actively monitoring the news, and 83 percent considered the nuclear accident the most important event of previous weeks. In terms of the national mass media, the number of those dissatisfied decreased, but the amount of those partly satisfied increased. Half of the respondents considered that the actual danger was higher in reality than the picture drawn by the mass media suggested. Some new problems were also mentioned: rumours and uncertain or questionable statements (serious health-damage effects, the temporary closing of schools, separated hospital wards) were disturbing for more than every second interviewee; 22 percent said that they had gathered information from a competent person (like a kindergarten teacher, a greengrocer, a healthcare worker or a scientist).

\section{SUMMARY AND CONCLUSIONS}

This study looked into the communication of the Chernobyl nuclear disaster in state-socialist Hungary at three different levels. It sought to reveal how information policymakers reacted to this unusual and politically highly sensitive case and what considerations may have affected their decisions. Based on the narrative analysis of the press, it is safe to conclude that the communication of the party newspaper was motivated by party loyalty rather than accuracy. During the studied period - with two notable exceptions - Népszabadság did not mention the rising levels of radiation but permanently informed readers about its reduction.

The findings obtained so far also highlight some of the characteristics of the authoritarian theory of the press (Siebert et al., 1956). In this approach, the press is a servant of the (party) state which is responsible for its content (ibid., pp. 9-37). The communiqués of the Hungarian Socialist Workers' Party showed that the Hungarian leadership was informed early on, but party leaders did not let the press publicise the news. Comparing official, top secret sources with public information in newspaper articles, the most remarkable thing is "permanent uncertainty". Leaders 
did not know what to communicate and how to communicate it. They had no crisis communication strategy to hand. Even though they received sufficient official information about the nuclear disaster and mentioned repeatedly that they must inform the people, they held back the facts from the public for several days. Despite the establishment of an expert group early on and discussions of the accident and its anticipated after effects by various party organisations, it is clear now that those most concerned, that is, the people, were not informed about the facts.

The party newspaper was "three days late" in reporting the disaster. Out of seven Chernobyl-themed front-page articles, only three had Hungarian relevance. From the studied eighteen articles, only two mentioned the rise in radiation, and three denied the existence of it. When nuclear radiation in the air was several thousand times above normal, the press published sentences like these: "there was no change in the measurement data" (Népszabadság, 30 April 1986, p. 4) or "the contamination of the air and of nature was not significant” (Népszabadság, 1 May 1986, p. 4). In the articles, the "indirect wording" was general. Some of them did not literally state that there was an increase in nuclear radiation, but the predication implied that the level of radiation had risen. The first accurate article was published "three weeks after the accident" on 19 May. By this time, the largest dose of harmful nuclear radiation had already left Hungary.

The uncertainty manifested itself in the opinion polls as "fear": half of the people were worried. According to the second poll, even though there was some positive news since the first survey - the level of nuclear radiation had reduced, the fire had been extinguished, expert statements and official reports were published and multiplied the number of the articles, showing a reduction in radiation in Hungary - people had not been calmed. Most interviewees complained about different kinds of anxiety and fear because of the accident and its unpredictable effects, and were not satisfied with the information provided. The insecure information guided people to gather information from alternative sources, and it generated disquieting rumour and gossip. In this respect, the communication of the incident did not have its intended effect but in fact was rather counterproductive.

The Chernobyl case suggests that Hungarian information policy showed minimal attribution of flexibility - it kept repeating the same health-protection instructions, publishing two articles which mentioned that harmful radiation had reached Hungary - "Not even a fatal accident could break the authoritarian media system"; because of the propaganda regime, the party leadership could not manage efficient communication and accurate information. They could not integrate this complex, geopolitical/social/healthcare case into an ideologically highly-charged discourse. As a result, people experienced a reality gap caused by the malfunctions of the information policy and felt angst. The main reason why decision-makers did not let the press publicise real measurement data was that confessing that the nuclear disaster was a sign of Soviet human and technological failure would have been at odds with the ruling ideological narrative. The Hungarian leadership was 
under pressure and sought not to damage the Soviet fair-weather relationship by reporting real facts.

This paper does not offer a representative picture on the information policy of the Kádár regime, but a little, yet important, segment of it. The case of Chernobyl has been chosen because it shows the dangerous consequences that propaganda had in Hungary. Further research is needed, including an extensive mass media content analysis for more generalisable findings to be obtained.

\section{REFERENCES}

1986. évi II. törvény a sajtóról [Press law 1986/II.] (1986). Retrieved February 11, 2017, from http:// www.okm.gov.hu/letolt/elektronikus_ugyintezes/ 1986evi2tv.pdf.

A WHO helyteleníti a reaktorbaleset miatti indokolatlan óvintézkedéseket. A világszervezet tájékoztatta az európai egészségügyi minisztereket [The WHO deplores unreasonable precautionary measures for reactor accidents. The World Health Organization informed the European health ministers] (May 8, 1986). Népszabadság.

Aszódi, A. (2006). Csernobil 20 éve [20 years of Chernobyl]. Fizikai Szemle, 4. Retrieved November 2, 2017 from http://fizikaiszemle.hu/archivum/fsz0604/aszodi0604. html.

Bajomi-Lázár, P. (2005). Médiapolitika [Media Policy]. In: P. Bajomi-Lázár (ed.), Magyar médiatörténet a késő Kádár-kortól az ezredfordulóig [Hungarian media history from the late Kádár-era until the millennium]. Budapest: Akadémiai Kiadó, pp. 19-51.

Beck, U. (1987). The anthropological shock: Chernobyl and the contours of the risk society. Berkeley Journal of Sociology, 32, pp. 153-165.

Csizmadia, E. (2012). Hatalom és ellenzék a Kádár-rendszerben. Az 1980-as első ellenzékről szóló határozat kontextusa [Power and opposition in the Kádár system. The context of the decision on the first opposition from 1980]. In: G. Földes \& M. Mitrovits (eds.), Kádár János és a 20. századi magyar történelem [János Kádár and 20th century Hungarian history], Politikatörténeti Füzetek 33. Budapest: Napvilág Kiadó, pp. 185-204.

Földes, G. (2012). Kádár János és a magyar desztalinizáció [János Kádár and the Hungarian de-Stalinisation]. Múltunk, 57(2), pp. 192-214.

Fordulópont a csernobili atomerőmü mentőmunkálataiban [A turning point in the rescue work of the Chernobyl nuclear power plant] (May 12, 1986). Népszabadság.

Harper, K. (2001). Chernobyl stories and anthropological shock in Hungary. Anthropological Quarterly, 74, pp. 114-123.

Határozott intézkedések a sugárveszély elhárítására. Nemzetközi sajtóértekezlet Moszkvában az ukrajnai erőmü-szerencsétlenségről [Determined measures are radiation hazard remediation. International press conference in Moscow on power plant catastrophe in Ukraine] (May 7, 1986). Népszabadság.

Hazánk légterében nem növekedett számottevően a radioaktivitás. Szakértői értekezlet a Polgári Védelem Országos Parancsnokságán [Radioactivity in our airspace has not increased significantly. Expert meeting at the National Civil Defense] (May 1, 1986). Népszabadság.

Hazánkban tovább csökkent a radioaktivitás [Radioactivity is further reduced in Hungary] (May 6, 1986). Népszabadság.

Hegedủs, I. (2001). Sajtó és irányítás a Kádár-korszak végén [Press and control in the end of the Kádár regime]. Médiakutató, 2, pp. 45-60.

HU OSA-420-2-2:1 A8203 (1986). Közvéleménykutatás a csernobili szerencsétlenség után [Opinion poll after the Chernobyl accident]. 
HU OSA-420-2-2:1 A8204 (1986). Újabb közvéleménykutatás a csernobili szerencsétlenség után [Opinion poll after the Chernobyl accident].

INSAG-7 (1992). The Chernobyl accident: Updating of INSAG-1, A report by the International Nuclear Safety Advisory Group. Safety Series, 75. Vienna: International Atomic Energy Agency, pp. 51-89.

Intézkedések a helyreállítás meggyorsítására. Szovjet párt- és állami vezetők látogatása Csernobilban [Measures to speed up recovery. Soviet party and state leaders visit Chernobyl] (May 4, 1986). Népszabadság.

Jakubowicz, K. (2011). Media Revolution in Europe: Ahead of the Curve. Strasbourg: Council of Europe Publishing.

Jelentés a hazai mérések eredményeiről [Report on the results of national measurements] (May 8, 1986). Népszabadság.

Jelentés a pénteki hazai sugárszintmérésről [Report on Friday’s measurement data] (May 10, 1986). Népszabadság.

Külföldi állásfoglalások és intézkedések [Foreign statements and instructions] (May 15, 1986). Népszabadság.

Lehülöfélben a csernobili reaktor. Összefoglaló a hazai sugárszintmérésekről [Chernobyl reactor is getting cool. Summary of the Hungarian measurement data] (May 19, 1986). Népszabadság.

MNL OL M-KS- 288. f. 22. cs. 86. ö.e.-1986 (May 16, 1986). Tájékoztató a Gazdasági Bizottság üléséről [Report on the meeting of the Economic Committee], pp. 689-694.

MNL OL M-KS- 288. f. 5. cs. 968. ö.e.-1986 4/b (appendix) (1986). Összehasonlitó táblázat és megjegyzések (Összeállitásra került a Müszaki Tanács közremüködésével.) [Comparative table and notes. (Report by the Hungarian Technical Council)].

MNL OL M-KS- 288. f. 5. cs. 968. ő.e.-1986. 4/b (May 6, 1986). Tájékoztató a Politikai Bizottság 1986. május 6-án megtartott ülésének 10. napirendi pontjához [Report to the agenda item No. 10 of the Political Committee's meeting held on 6 May].

MNL OL M-KS- 288. f. 5. cs. 968. ő.e.-1986. 4/c (May 6, 1986). Szó szerinti jegyzőkönyv a Politikai Bizottság üléséröl (1986. május 6.) [Literal report on the Political Committee meeting].

MNL OL XIX-A-2af-Ma-00147-VII-szn/1986. (IpM M-2523) (April 29, 1986). Kapolyi László ipari miniszternek a csernobili atomerömü balesetről szóló első tájékoztatása Marjai József miniszterelnök-helyettes részére (1986. április 29.) [László Kapolyi industrial minister’s first information about the Chernobyl nuclear power plant accident to József Marjai Deputy Prime Minister].

MNL OL XIX-A-41-II. sorozat-Elnöki iratok-10/III. t.-sz. n.-Feljegyzés 1986. május 5 (May 5, 1986). Összefoglaló jelentés a csernobili atomerömüben bekövetkezett balesetröl, annak hazai következményeiröl, és elhárításukra tett intézkedésekröl. In. Jelentés a csernobili balesetröl, annak magyarországi hatásairól és a magyar hatóságok intézkedéséröl (1986. május 5.) [Summary report on the Chernobyl nuclear accident, its national consequences and measures].

MNL OL XIX-A-41-II. sorozat-Elnöki iratok-10/III. t.- sz.n.-1986. május 8 (May 8, 1986). Az Országos Atomenergia Bizottság Titkárságának feljegyzése az atomerömü-baleset várható magyarországi hatásairól (1986. május 8.) [A note from the Secretariat of the National Atomic Energy Commission on the expected impacts of the nuclear accident in Hungary].

MNL OL XIX-A-83-a-848. jkv-5. np.-1986. 5/c (1986). Jelentés a Minisztertanács részére [Report to the Council of Ministers].

MNL OL XIX-A-83-a-848. jkv-5. np.-1986. (1986). Szó szerinti jegyzőkönyv a Minisztertanács üléséröl (1986. május 8.) [Literal report on the Cabinet's meeting].

MNL OL XIX-B-1-ai-1-a-579/1986. (April 30, 1986). Berki M. a Polgári Védelem Országos Törzsparancsnokának jelentése Kárpáti Ferenc honvédelmi miniszter részére az atomerőmüben történt balesetröl (1986. április 30.) [Berki, M. Commander of National Civil Defense's report about the Chernobyl nuclear power plant accident to Ferenc Kárpáti, Minister of Defense]. 
MNL OL XIX-B-1-y-1986.05.12. 7/b (May 12, 1986). Részlet belügyminiszteri értekezlet szó szerinti jegyzőkönyvéből (1986. május 12.) [Detail from the Ministry of the Interiors report].

Normalizálódik a légkör sugárszintje a csernobili atomszerencsétlenség után. Természetes érték a levegöben [Radiation of the atmosphere is normalized after Chernobyl nuclear disaster. Natural value is airborne] (13 May, 1986). Népszabadság.

Romsics, I. (1999). A Kádár-korszak. In: I. Romsics (ed.), Magyarország története a XX. században. Budapest: Osiris Kiad, pp. 269-380.

Sajtóértekezlet Moszkvában Csernobil orvosi vonatkozásairól [Press conference in Moscow about the medical aspects of Chernobyl] (May 16, 1986). Népszabadság.

Siebert, F. S., Peterson, T., \& Schramm, W. (eds.). (1956). Four Theories of the Press. Urbana-Chicago: Chicago University Press.

Sipos, B. (2010). Média és demokrácia Magyarországon. A politikai média jelenkortörténete. [Media and democracy in Hungary. The contemporary history of political media]. Budapest: Napvilág Kiadó.

Sipos, B. (2015). Szempontok a Horthy-kor és a Kádár-kor nyilvánosságának vizsgálatához-összehasonlításához [Viewpoints for comparing the publicity of Horthy and the Kádár era]. Me.Dok: Média-Történet-Kommunikáció, 3, pp. 27-42.

Szatmáry, Z., \& Aszódi, A. (2005). Csernobil. Tények, okok, hiedelmek [Chernobyl. Facts, reasons, beliefs]. Budapest: Typotex.

Szerencsétlenség egy szovjet atomerőmüben [Trouble in a Soviet nuclear power plant] (April 29, 1986). Népszabadság.

Szovjet állásfoglalás a Csernobil körüli nyugati propagandakampányról. A kormány köszönete a külföld segítőkészségéért [Soviet resolution on the Western propaganda campaign around Chernobyl. The government thanks for the help of the rest of the country] (May 5, 1986). Népszabadság.

Takács, R. (2009). A sajtóirányítás szervezete a Kádár-korszakban [Institutionalization of the press control during the Kádár era]. Médiakutató. Retrieved April 11, 2017 from http://www.mediakutato.hu/cikk/2009_03_osz/07_sajtoiranyitas_kadar/.

Takács, R. (2012). Politikai újságírás a Kádár-korban. Hatalom és újságírás viszonya 1956-1988 [Political journalism in the Kádár era. Relationship between power and journalism 1956-1988]. Budapest: Napvilág Kiadó.

Takács, R. (2013). Desztalinizáció Közép- és Kelet-Európában [De-Stalinization in Central and Eastern Europe]. Múltunk, 3, pp. 68-103.

Tart a küzdelem a csernobili atomerőműnél [Continuous struggle at the Chernobyl nuclear power plant] (May 9, 1986). Népszabadság.

Terestyéni, T. (2009). Volt egyszer egy Tömegkommunikációs Kutatóközpont... [Once upon a time there was a Mass Media Research Center of Hungary]. Retrieved April 15, 2017 from http://communicatio.hu/mktt/hirek/konferenciak/2009/tk40/nyitoeloadas.htm.

Újabb jelentés a csernobili atomszerencsétlenségről. Szovjet intézkedések a sugárszennyeződés ellen. Hazánk légkörében nem növekedett a radioaktivitás [Another report on Chernobyl nuclear disaster. Soviet measures against radiation contamination. Radioactivity did not increase in Hungary's atmosphere] (April 30, 1986). Népszabadság.

Valuch, T. (2005). A „gulyáskommunizmus” [Goulash communism]. In: I. Romsics (ed.). Mítoszok, legendák, tévhitek a 20. századi magyar történelemröl [Myths, legends, and misbeliefs about 20th century Hungarian history]. Budapest: Osiris Kiadó, pp. 361-390.

Vásárhelyi, M. (2016). Média- és közvélemény-kutatás a Kádár-korszakban [Media and opinion polls in the Kádár era]. Médiakutató, 1, pp. 93-96. 